\title{
Bilateral optic perineuritis associated with $p$-ANCA vasculitis
}

Ivan Cheng En Yoo, Yong Meng Hsien, Mushawiahti Binti Mustapha, Jemaima Che Hamzah

Department of Ophthalmology, Universiti Kebangsaan Malaysia Medical Centre (UKMMC), Cheras, Wilayah Persekutuan Kuala Lumpur, Malaysia

\section{Abstract}

A 69-year-old Chinese woman with underlying perinuclear anti-neutrophil cytoplasmic antibody associated with vasculitis ( $\mathrm{p}$-ANCA vasculitis) with no previous history of ocular involvement experienced one week of blurred vision in both eyes associated with pain. Ophthalmological evaluation demonstrated severe visual loss in both eyes, with pale optic discs but without other signs of ocular vasculitis. Magnetic resonance imaging (MRI) of the brain and orbit revealed bilateral enhancement of the optic nerve sheath with classical tram-track and doughnut signs. Intravenous methylprednisolone was given for five days and marked improvement of vision was seen.

In patients with p-ANCA vasculitis, bilateral optic perineuritis (OPN) is uncommon but can be one of the treatable causes to be considered, with good response to prompt steroid treatment.

Keywords: Bilateral optic perineuritis (OPN), Perinuclear anti-neutrophil cytoplasmic antibody associated vasculitis ( $\mathrm{p}$-ANCA vasculitis)

Correspondence: Dr. Yong Meng Hsien, Department of Ophthalmology, Universiti Kebangsaan Malaysia Medical Centre (UKMMC), Jalan Yaacob Latif, Bandar Tun Razak, Cheras, 56000, Kuala Lumpur. E-mail:yongmenghsien@ppukm.ukm.edu.my 


\section{Perineuritis optik pada kedua-dua mata yang dikaitkan dengan vasculitis p-ANCA}

\section{Abstrak}

Seorang wanita Cina berusia 69 tahun yang telah didiagnosakan mendapat vaskulitis akibat antibodi perinuklear anti-neutrofil sitoplasma (vaskulitis p-ANCA) tanpa sebarang masalah okular sebelumnya,mengalami masalah penglihatan kedua-dua mata menjadi kabur dan kesakitan. Pemeriksaan oftalmologi menunjukkan kehilangan penglihtan yang teruk pada kedua-dua belah mata, dengan cakera optik yang pucat tetapi tanpa tanda-tanda vaskulitis okular yang lain. Pencitraan resonans magnetik (MRI) otak dan orbit mendedahkan peningkatan sarung saraf optik dengan tanda klasik; trek tram dan donat. Metiprednisolone intravena diberikan selama lima hari dan keadaan pulih dengan baik.

Kejadian perineuritis optik (OPN) pada kedua-dua belah mata adalah tidak lazim pada pesakit p-ANCA vaskulitis. Tetapi ianya boleh menjadi salah satu penyebab OPN yang boleh dirawat, dan bertindakbalas dengan baik terhadap rawatan steroid.

Kata kunci: perineuritis optik (OPN), perinuklear anti-neutrophil antibodi sitoplasmik yang berkaitan dengan vaskulitis (p-ANCA vaskulitis)

\section{Introduction}

Optic perineuritis (OPN) is a rare inflammatory disorder of the optic nerve sheath. It can be either isolated and idiopathic or manifested as part of a systemic inflammatory disease. Perinuclear anti-neutrophil cytoplasmic antibody associated vasculitis (p-ANCA vasculitis) on the other hand is a systemic inflammatory disease which mainly affects the small blood vessels. Common ocular manifestations are scleritis, uveitis, peripheral ulcerative keratitis, and other ocular inflammatory disease. We report a case of bilateral OPN associated with p-ANCA that responded well to systemic corticosteroids treatment.

\section{Case presentation}

A 69-year-old Chinese woman with underlying $\mathrm{p}$-ANCA vasculitis without previous ocular involvement experienced blurring of vision in both eyes (OU) associated with eye pain for one week. Ophthalmological examination showed visual acuity (VA) of hand movement in the right eye (OD) and no perception of light in the left eye (OS) with sluggish pupil reflexes OU. Fundus examination revealed pale optic discs OU 
with no inflammatory changes over the vessels, retina, or choroid. Ocular motility was normal, no ptosis or proptosis noted. Anterior segment examination was unremarkable with pseudophakic lens OU.

This lady was diagnosed with p-ANCA vasculitis in 2014 when she presented with peripheral neuropathy with erythematous papules on bilateral lower limbs. Blood tests showed raised erythrocyte sedimentation rate (ESR) and were p-ANCA positive. Skin punch biopsy was done and revealed leukocytoclastic vasculitis. Nerve conduction study showed diffuse axonal sensorimotor polyneuropathy. She was on oral prednisolone $40 \mathrm{mg}$ once daily, commenced in April 2014, and azathioprine since May 2014. Her disease achieved remission in November 2014. However, she had multiple relapses and was having a disease flare-up during this presentation.

Laboratory findings were as follows: white blood cell (WBC; $14.2 \times 109 \mathrm{~g} / \mathrm{L}), \mathrm{ESR}$ (120 mm/hour) and c-reactive protein (CRP; $25 \mathrm{mg} / \mathrm{L})$ were raised. Serology for Treponema pallidum, antinuclear antibodies, C3/C4 complement level, anti double-stranded DNA, and chest X-ray with Mantoux test were all normal. Magnetic resonance imaging (MRI) of the brain and orbit showed that there was evidence of bilateral optic nerve sheath enhancement with classical "tram-track" (Fig. 1) and "doughnut" (Fig. 2) signs indicating active inflammation of the optic nerve sheath, without the involvement of other brain structures.

Fundus fluorescein angiography (FFA) was performed and showed no positive finding (Fig. 3). There was no FFA evidence of optic disc or posterior segment inflammation or anterior ischemic optic neuropathy. Subsequently, the patient was subjected to visual evoked potentials. Amplitudes of P100 were reduced OU, with OS $(1.8 \mu \mathrm{V})$ more affected than OD $(4.1 \mu \mathrm{V})$, which corresponds to the degree of visual impairment noted in respective eyes.

Diagnosis of bilateral OPN was made in view of the classical findings in the optic nerve imaging and negative FFA. The patient was co-managed with her neurologist for her recurrent systemic vasculitis leading to her OPN. Treatment with intravenous steroids was administered (methylprednisolone $250 \mathrm{mg}$ QID for 5 days), then replaced with oral prednisolone $40 \mathrm{mg}$ once daily for 1 month, then tapered by 5 mg every 2 weeks. Her VA improved during the first few days of intravenous steroid treatment and maintained at 6/18 OD and 6/36 OS in the subsequent follow-up. Despite the improvement in vision, her pale optic discs OU remained the same, suggesting it was an acute on chronic attack even though the patient was unable to recall any previous episode.

\section{Discussion}

OPN is a rare orbital inflammatory disorder which can be secondary to systemic inflammatory disease, in the case of our patient $p$-ANCA vasculitis. $p$-ANCA vasculitis 


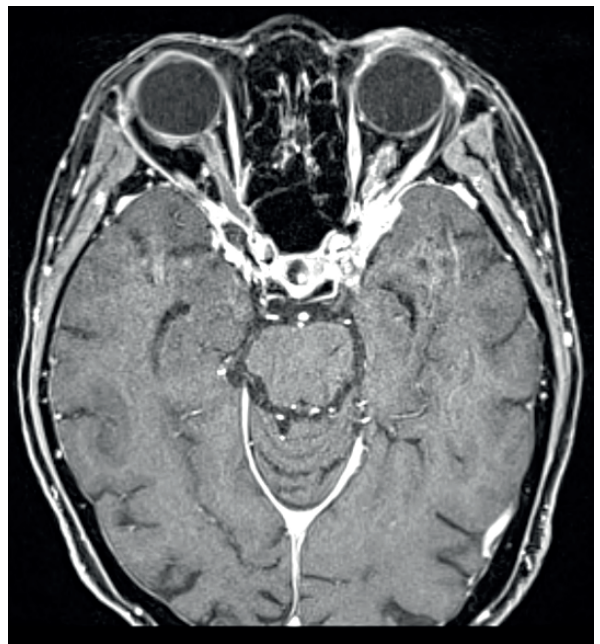

Fig. 1. "tram-track" sign (axial view; MRI T1W post-contrast).
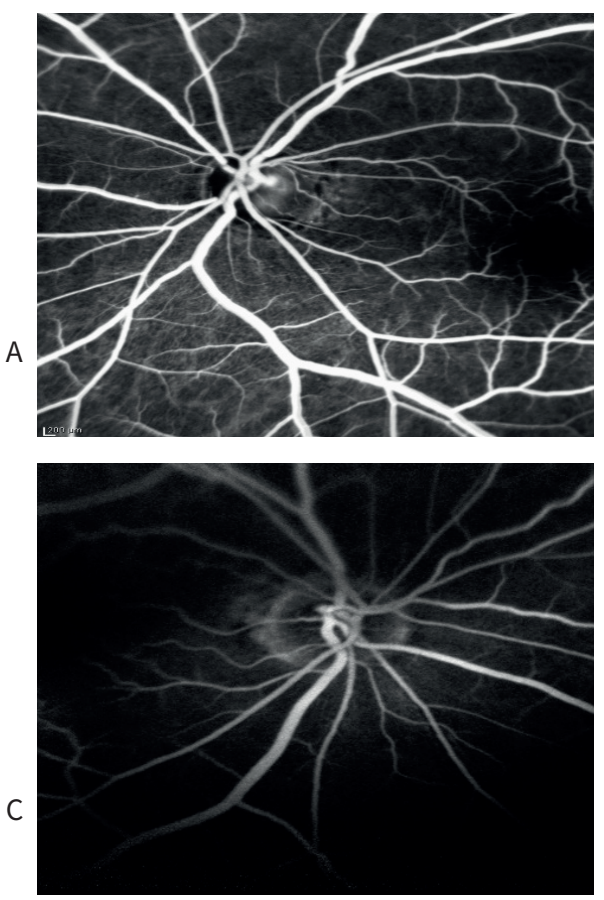

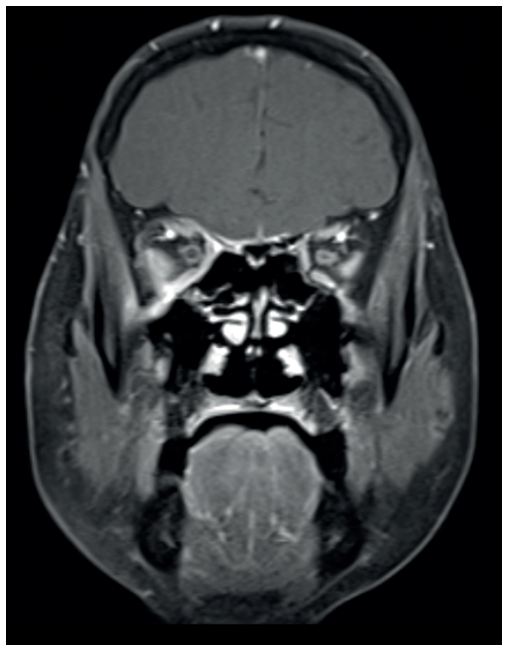

Fig. 2. "doughnut" sign (coronal view; MRI T1W post-contrast).

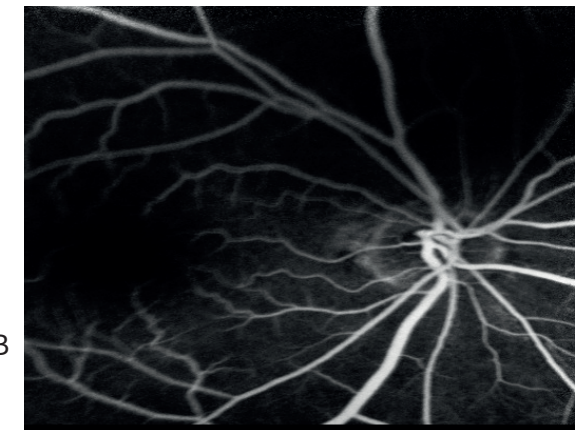

D

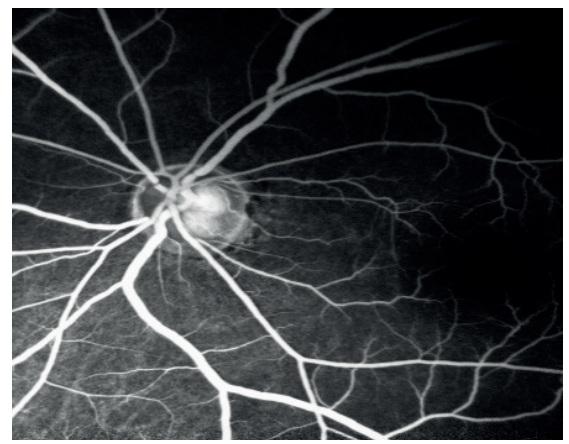

Fig. 3. Normal FFA OU. (A) RE at $1 \mathrm{~min}$; $(B)$ RE at $6 \mathrm{~min}$; (C) LE at $1 \mathrm{~min}$; $(D)$ LE at 6 min. 
is a systemic inflammatory disease which mainly affects the small blood vessels. There are two previous studies looking at the ocular manifestations of patients with systemic p-ANCA vasculitis (four cases each), which reported that systemic vasculitis predominantly affects the vascular components of the ocular tissues, e.g. scleritis, retinal vein occlusion, choroiditis, and ischemic optic neuropathy, in their case series. OPN on the other hand was not well documented as a potential complication of systemic vasculitis. ${ }^{1,2}$ In cases of OPN, the optic nerve sheath is the main target of the inflammatory response, and reduction of VA is secondary to optic nerve compression by the inflamed and thickened optic nerve sheath. ${ }^{3}$

Subjects suffering from OPN commonly present with acute or subacute monocular visual loss, with eye pain exacerbated by ocular movement. ${ }^{4}$ Bilateral visual loss is uncommon in OPN but should not be a surprise in cases of systemic involvement as in our patient. Visual field involvement in OPN can be variable; however, it tends to spare the central vision. ${ }^{5}$ Brain and orbit MRI typically demonstrates pathological enhancement around the optic nerve with classical signs such as the "tramtrack" sign on axial view and the "doughnut" sign on coronal view, and both are best depicted on MRI T1 post gadolinium.

It is important to investigate for other more common causes with similar presentation. Intracranial pathology with raised intracranial pressure or compressive optic neuropathy should be ruled out with brain and orbit MRI. Ischemic optic neuropathy usually presents as a painless condition without optic nerve sheath inflammation. Optic neuritis should be considered when an inflammatory process is involved, but optic neuritis commonly involves a younger age group, whereas OPN can be manifested in a broad age range.

The treatment option for both OPN and systemic vasculitis is a high dose and longer duration of corticosteroid, which can reduce the inflammation, minimize risk of recurrence, and prevent relapses. ${ }^{6}$ The Optic Neuritis Treatment Trial demonstrated that intravenous pulse steroid may not affect the visual outcome in cases of optic neuritis. In contrast, in cases of OPN a delay in steroid treatment may cause irreversible visual loss. ${ }^{7}$

\section{Conclusion}

It is important to accurately diagnose OPN and initiate treatment early as there may be recurrence of visual loss, and in some cases irreversible loss of vision, unless treated with corticosteroids. OPN can be secondary to a systemic inflammatory disorder, in this case p-ANCA vasculitis. MRI plays a vital role in the diagnostic workup and subsequent management. 


\section{References}

1. Matsuo T. Eye manifestations in patients with perinuclear antineutrophil cytoplasmic antibody-associated vasculitis: case series and literature review. Jpn J Ophthalmol. 2007;51(2):131-138.

2. Dandekar SS, Narendran NN, Edmunds B, Graham EM. Ocular involvement in systemic vasculitis associated with perinuclear antineutrophil cytoplasmic antibodies. Arch Ophthalmol. 2004;122(5):786787.

3. Morotti A, Liberini P, Padovani A. Bilateral optic perineuritis as the presenting feature of giant cell arteritis. BMJ Case Rep. 2013. doi: 10.1136/bcr-2012-007959

4. Purvin V, Kawasaki A, Jacobson DM. Optic perineuritis: clinical and radiographic features. Arch Ophthalmol. 2001;119(9):1299-1306.

5. Hykin PG, Spalton DJ. Bilateral perineuritis of the optic nerves. J Neurol Neurosurg Psychiatry. 1991;54(4):375-376.

6. Tatsugawa M, Noma H, Mimura T, Funatsu H. High-dose steroid therapy for idiopathic optic perineuritis: a case series. J Med Case Rep. 2010;4:404.

7. Lai HW, Yang N, Ho CK. Optic perineuritis: an important differential diagnosis of optic neuritis. HK J Ophthalmol. 2013;17(1):11-17. 